\title{
INVESTIGATING THE PROBLEM ENCOUNTERED BY STUDENT'S IN WRITING THE RECOUNT TEXT
}

\begin{tabular}{c} 
Nur Aeni M \\
nur_aeni@unm.ac.id \\
Universitas Negeri Makassar, Indonesia \\
Muthmainnah \\
Universitas Al Asyariah Mandar, Indonesia \\
\hline
\end{tabular}

\section{INTRODUCTION}

\section{Background}

It has been realized that writing is one of English skills that must be mastered by the English language learners. Writing is a form of communication that allows students to put their feelings and ideas on paper, to recognize their knowledge and beliefs into convincing arguments, and to convey meaning through well constructed text. It's most advanced form, written expression can be as vivid as a work of art. As children learn the steps of writing, and as they build new skills upon old, writing evolves from the first simple sentences to elaborate stories and essays. Spelling, vocabulary, grammar, and organization come together and grow together to help the student demonstrate more advanced writing skills each year. Jonah(2006:29) argues that writing can be used as an indirect means of communication to other convey information. Activities is not easy to write bacause writing should be able to produce something new and can give you an idea or ideas to the reader through writing.

One of productive skills which is very important to be mastered by English learners is writing skill. Richard and Renandya (2002: 303) state that writing is the most difficult skill for second language and foreign language learners. Furthermore, they claim that writing is not only generating and organizing ideas of our mind, but also translating these ideas into a readable text. Based on their arguments, it seems common that many learners particularly those of foreign language learners have some degrees of difficulties in writing. Therefore, some efforts need to be done in order to maintain or improve the students' writing skill.

On the teaching and learning process of writing, there are some kinds of media: visual media, audio media and audiovisual media used to improve the students' writing skill. The use of those media is expected to minimize the students' constraints in writing mentioned above. For that reason, the researcher applied movies that are expected to improve students' writing skill. It is because movies can help the students explore and develop ideas as well as contents to write. In addition, a movie can guide the students to construct their texts through its story. Related to this, Champoux (2003) states that movies in literature studies suggest some unique features that make them uncommonly powerful learning tools. Some unique aspects of movies let the media show organizational behavior and management concepts in an uncommonly powerful way. It is also argued that these aspects of movies will help students understand how viewing movies can improve their learning.

Recount is a genre that student learns in the writing English, this next is written with the purpose is either to inform or to entertain the readers about event in the past. According to Hyland on sixty writing process (2004), "A recount is a text that tells about past experiences or events" (p.iii). On the other hand, recount can explain about the student's life story.

Based on the students' problems above, a way that makes the students interested in writing has to be developed. One way that can help the students appreciate and be more interested in writing is providing suitable writing materials and learning media. In writing recount text, the students sometimes have the difficulty in terms of grammar and vocabulary. Actually, the student's difficulties in writing recount text are mainly the lack of vocabulary and grammar. The students sometimes forget with the past form of a word. In writing recount text, the teacher should expalin more about grammar especially past tense and learn more vocabulary because it is the first problem in student writing.

The following are the question that should be answer related to the background of the study :

1. What are the students' problems in writing recount text? 
2. What is the solution of the students problem in writing recount text?

\section{LITERATURE REVIEW}

\section{Previous related studies}

Wahyuni Pela Sari (2014) Based on the research question, the researcher found the various answers by the participants. They had difference answers from the researcher question about the problem in writing recount processes. Finding from this study, the researcher found the same categories with the expert's explanation about student's problem in writing as foreign language, so that the researcher used deductive approach and also researcher got many new categories. The new categories made by the researcher because this research was inductive. The researcher explained the categories problem that found in the processes of writing when researcher done interview and analysis the data.

Dwi Supatmi (2013) The research finding is presented as the answer of the problem statements. The writer divides it into two parts, namely; difficulties faced by the students in writing recount text, and the teacher's solution for the problem faced by the students in writing recount text at the second year of SMPN 2 Kartasura.

Allieni Harris, Mohd. Ansyar, Desmawati Radjab (2014) Based on the findings, it can be concluded that the students' writing ability in recount texts at the tenth grade of SMA N 1 Sungai Limau is low. It is based on the analysis of all of indicators in this research, concerning with generic structure and language features of recount texts. Then, the low of students' ability in writing recount texts is because some difficulties faced by students. The difficulties are dealing with the language features of recount texts. It is proven by the data of students' writing recount texts. It was found that students did many mistakes in using simple past tense, action verb, linking verb, and pronoun. In addition, based on the analysis of students' writing, it was found some causes that made students did some mistakes in writing recount texts. The first cause is interlingual transfer. The students' mother tongue was still influenced the way of students' writing. The next cause of students' difficulties is intralingual transfer. It related with the students' knowledge in using correct grammar. Students had lack of grammar knowledge that made them did many errors in their writing. The last cause of students' difficulties in writing recount texts is lack of vocabulary. Based on students' writing, it was found that students used some inappropriate vocabulary to show their ideas.

Wahyuni , Mochtar Marhum , Muhsin (2014) Before conducting the research, the researcher observed the teaching and learning process in the classroom by using observation checklist. The material given to the students was based on the one textbook. The teacher did not prepare the materials from the other sources which were relevant to recount text. She did not use certain methods or techniques in teaching learning process. It made students uninterested in learning about how to make recount text. Moreover, she did not motivate the students. In learning process, the students and the teacher discussed about materials to improve their skills in recount text. The teacher gave them an example of recount text based on text book when one of the students asked her. Although the teacher guided the students to write recount text, but most of the students did not write based on the steps in writing recount text. The result, when the teacher asked the students to read their writing in front of the class, was only 4 out of 28 students who could do it. The teacher only looked and listened to the students. She did not evaluate recount text that was made by the students. Moreover, the students were not asked by the teacher to made conclusion about the materials in the end of learning process.

Based on some related previous studies that it can be concluded that there are still many problems encountered by students in writing the recount text.

\section{Some pertient ideas}

a) A definition of writing

Writing is a process to get product. The final product is measured against a list of criteria which includes content, organization, vocabulary use, grammatical use, and mechanical considerations such as spelling and punctuation (Fauziati, 2008: 143). Muray (1980) in Richards (1997: 108) distinguishes three stages in writing: pre-writing, drafting, and revising.

According to Richards (1997: 100) "learning to write well is a difficult and lengthy process, because it induces anxiety and frustration in many learners". In this case, the writer will observe the difficulties in English learning process in writing recount text in SMP N 2 Kartasura. We know SMP N 2 Kartasura is one of the favorite schools in Kartasura. The students should be excellent in studying English especially writing skill. In writing recount text, the students sometimes have 
the difficulty in terms of grammar and vocabulary. Actually, the student's difficulties in writing recount text are mainly in the lack of vocabulary and grammar. For example to change V1 (present tense) to V2 (past tense), go become went, like I go to Baron beach last month. The sentence is wrong, and actually the correct sentence is I went to Baron beach last month. The students sometimes forget with the past form of a word. In writing recount text the teacher should explain more about grammar especially past tense and learn more vocabulary because it is the first problem in students writing.

b) Characteristic of writing

According to Boardman (2008:18-25) There are three characteristics in writing a good text or paragraph, namely:

1. Coherence

A paragraph has coherence when the supporting sentences are ordered according to a principle. The sentences are put in order so that the reader can understand your ideas easily. The principles for ordering depend on the types of paragraph you are writing. Coherence means stick together, coherence is basically a matter of having the part of a piece of writing in the right with the clear process.

2. Cohesion

Another characteristic of a good paragraph is Cohesion. When a paragraph has cohesion, all the supporting sentences connect to each other in their support of the topic sentence.

3. Unity

The final characteristic of a well-written paragraph is unity. All the supporting sentences should relate to the topic sentence. Order in text or paragraph is like organization easy, but is smaller in space so it may be simpler to consider order as direction. Thus order chronological steps to express the idea the written form.

c) Benefits of writing

Writing is essential. It brings about a lot of advantages (cf. Chappell, 2011; or What is the importance of writing?) since it helps to:

Express one's personality;

Foster communication;

Develop thinking skills;

- Make logical and persuasive arguments;

- Give a person a chance to later reect on his/her ideas and re-evaluate them;

- Provide and receive feedback; and

- Prepare for school and employment.

As Walsh (2010) says: Writing is important because it's used extensively in higher education and in the workplace. If students don't know how to express themselves in writing, they won't be able to com-municate well with professors, employers, peers, or just about anyone else. Much of professional communication is done in writing: proposals, memos, reports, applications, preliminary interviews, e-mails, and more are part of the daily life of a col-lege student or successful graduate. Writing has a unique position in language teaching since its acquisition involves a practice and knowledge of other hree language skills, such as listening, reading and speak-ing. Moreover, it requires mastering of other skills, such as metacognitive skills. Learners need to set an objective for their writing, plan it carefully, think over its layout and logical structure, revise it

d) A definition of recount text

As stated by Anderson (1997), recount is defined as a piece of text that retells events aimed to give the audience a description of what occurred and when it occurred. In line with that, Watkins (2005) states recounts are sequential texts that do little more than sequence a series of events. On Indonesia curriculum the students should learn this text type because recounts are the simplest text type rather than the other genre. So, the students also have to master this subject.

Based on the definition of recount above, it can be concluding that recount as a piece of text that reconstruct past events which they happened in order and related in a particular relation. Based on Anderson (1997), the students have to know how to construct and what language features in a recount.

e) Component and language features of recount text :

Based on Anderson (1997), the students have to know how to construct and what language features in a recount.

The components of a recount text are:

- A first paragraph: Orientation which explains about background of information about who, what, where and when. 
- A series of paragraph that retell the events in the order in what they happened

- A concluding paragraph

The students have to know about it. It is because the students will be easier to write a recount text if they know the construction. Language features in a recount text are:

- Proper nouns

- Descriptive words

- The use of the past tense

- Words

In line with that, according to Ngabut (2003), in order to be able to construct a recount text effectively, the students should know well the steps that should be followed. There are six steps of how to write a recount text effectively. The steps are: (1) prepare what information required based on the theme or the topic, (2) provide the setting and introduce participants in orientation, (3) determine the events that occur based on its sequences, (4) summarize the events in reorientation, (5) arrange all information to make first draft, and (6) analyze the first draft especially in structure of text, vocabulary and grammar conjunction, spelling and punctuation. From the description before, it can be concluded that recount has three elements:

f) Constructing in Written Recount Text

Boardman (2008:287) stated that the steps for constructing of written recount text are:

- The First paragraph that give background information about who, what, where and when. It is called onorientation.

- A record of events usually recounted in chronological order, named; event 1 , event 2 , event 3.

- A personal comment and or evaluative remarks, which are interspersed throughout the record of events named evaluation.

- A reorientation which "rounds off "the sequences of events or retell about what happened in the end.

Boardman (2008:287) the language features usually found in a recount:

- Use of nouns and pronouns to identify people, animals or things involved.

- Use of past action verbs to refer the events.

- Use of past tense to located events in relation to speaker`s or researcher`s time.

- Use conjunctions and time connectives to sequence the event.

- Use of adverb and adverbial phrases to indicate place and time.

- Use of adjectives to describe nouns.

According Boardman (2008:287) in making of functional grammar, the significant common grammatical patterns of recount include:

- Focus on specific participant.

- Use of material process or action verb.

- Circumstance of time and place.

- Use past tense and focus on temporal sequences.

\section{RESEARCH METHODOLOGY \\ Research design}

In this research, the researcher used qualitative research. According to Bodgan and Taylor in Setiyadi, qualitative research is research that produces descriptive data in form of written words or oral from the subject and it behavior that can be observed, therefore the goal is an individual understanding and its background completely. The descriptive qualitative method is used to investigate the students problem in writing recount text. Sugiono stated that qualitative research has natural setting as the direct source of data and researcher is the key instrument, dynamic in looking the object, based on a real object, holistic, and there was not influences from others. In this research, the role of research is investigating the problem faced by the students, then identified the problem, and finally find the solution of the students problem in writing recount text.

\section{Population and sample}

The writer determined population and sample before conducting the research. The explanation about population and sample is provided below.

a. Population 
Population according to Sugioni (2010:117) Population is geographic generalization there are : object/subject has quality and certain of characteristic taht set by researcherto learning then make conclution. Based on the statements above, the writer chooses the students of SMP Negeri 1 Pa'jukukang as the population of the study.

b. Sample

Donal Ary stated that sample is part of population or the representation of a population. A sample is a small proportion of a population selected for observation and analysis.

\section{Technique of data collection}

In this study, the researcher uses several techniques in collecting the data: observation, interview, and questionnaire.

a. Observation

Gorman and Clayton define observation studies as those that "involve the systematic recording of observable phenomena or behaviour in a natural setting" (2005,p.40). Observation is one of techniques that help the researcher to gain the data in qualitative method research. This technique was used in order to get information directly about the behavior, situation, or attribute of the population. In addition, this technique uses to anticipate the insufficiency of questionnaire. Moreover, the researcher also uses the observation checklist as the guideline in observing the students.

b. Interview

Interview is the way to get supporting data through face to face conversation between an interview. Mack stated that the interview is a technique designed to elicit a vivid picture of participant's perspective on the research topic. The researcher interviewed the English teacher to get the data about the students' problem in writing recount text and the solution of the students' problem in writing recount.

c. Questionnaire

Questionnaire is a list question that used by obtaining information from respondent. From collecting data through questionnaire, the researcher found out the causes of the students' problem in writing recount text. In this research, the researcher used closed question to the students. In this case, instruct the respondents to answer by selecting from a range of two or more option supplied on the questionnaire.

\section{BIBLIOGRAPHY}

Harris, A., Ansyar, M., \& Radjab, D. (2014) An analysis of students' difficulties in writing recount text at tenth grade of SMAN 1 Sungai Limau.

Wahyuni. Marhum, \& M., Muhsin. (2014). Analyzing errors made by the grade viii

students in writing recount text.

Saragih, N., Silalahi, R., \& Pardede, H. (2014) The effectiveness of using recount text to improve writing skill for grade iii students of Kalam Kudus elementary school 2 Pematangsianta.

Supamti, D. (2013) Students' difficulties in writing recount text at the second year of smp n 2 Kartasura in $2012 / 2013$ academic year.

Sari, W.P., Imelwaty, S., Alicia, D. (2014) Students' problems in the process of writing recount text.

Klimova, B.F. (2012) The importance of writing.

Amelia, S., Lubis, N. D. A., \& Balatif, R. (2020). MIKROORGANISME DAN BAHAN PANGAN. Penerbit Qiara Media.

Amelia, S., Lubis, N. D. A., Siregar, M. A., \& Rozi, M. F. (2018). Research Article Antimicrobial Effect of Wasabia japonica or Wasabi on Raw Salmon in Served Sashimi at Japanese Restaurants in Medan.

Nasution, I. K., Lubis, N. D. A., Erwin, I., \& Nusa, M. I. (2018). Cognitive Function Differences based on Hemispheric Lesions of First-Ever Ischemic Stroke Patients. Ethnicity, 31, 44-30.

Lubis, N. D. A., Amelia, S., \& Balatif, R. (2020). Microbial Content Test on Sliced Papaya in Area of Universitas Sumatera Utara. Journal of Saintech Transfer, 3(2), 86-92.

Lubis, N. D. A., \& Sari, M. I. (2016, December). Body Mass Index and Triglyceride Levels of the Students of Faculty of Medicine University of North Sumatra 2016. In 1st Public Health International Conference (PHICo 2016). Atlantis Press.

Lubis, N. D. A., \& Lubis, H. A. P. (2016). Korelasi Indeks Massa Tubuh dengan Kebugaran Kardiorespirasi pada Siswa SMA Sutomo 2 Medan.

Lubis, N. D. A., Panggabean, M., \& Ichwan, M. (2020, November). Penguatan Sumberdaya Keluarga Dalam Mempercepat Perbaikan Gizi Masyarakat. In Talenta Conference Series: Agricultural and Natural Resources (ANR) (Vol. 3, No. 2).

Nasution, I. K., Lubis, N. D. A., Amelia, S., \& Hocin, K. (2018, March). The correlation of pain intensity and quality of life in chronic LBP patients in Adam Malik general hospital. In IOP Conference Series: Earth and Environmental Science (Vol. 125, No. 1, p. 012183). IOP Publishing.

Kusnadi, J. (2018). Pengawet Alami untuk Makanan. Universitas Brawijaya Press.

Amelia, S., Lubis, N. D. A., Balatif, R., Rozi, M. F., \& Sidhi, S. P. (2020, January). Antibacterial effect of Andaliman (Zanthoxylum acanthopodium) against contaminant in raw common carp (Cyprinus carpio Linnaeus). In IOP Conference Series: Earth and Environmental Science (Vol. 425, No. 1, p. 012036). IOP Publishing. 
Amelia, S., Lubis, N. D. A., Rozi, M. F., \& Nababan, I. F. F. (2018, November). Safe processing method and storage time threshold for consuming of powdered-infant formula based on total plate count test. In IOP Conference Series: Earth and Environmental Science (Vol. 205, No. 1, p. 012033). IOP Publishing.

Amelia, S., Lubis, N. D. A., Siregar, M. A., \& Rozi, M. F. (2018). Research Article Antimicrobial Effect of Wasabia japonica or Wasabi on Raw Salmon in Served Sashimi at Japanese Restaurants in Medan.

Rosli, M. H. (2018). Korelasi Antara Status Gizi dan Status Anemia Terhadap Indeks Prestasi (IP) Mahasiswa Malaysia yang Studi di Universitas Sumatera Utara.

Lubis, N. D. A., \& Sari, M. I. (2016, December). Body Mass Index and Triglyceride Levels of the Students of Faculty of Medicine University of North Sumatra 2016. In 1st Public Health International Conference (PHICo 2016). Atlantis Press.

Lubis, N. D. A., Nasution, T. A., Wahyuni, D. D., \& Feriyawati, L. (2020, November). Gambaran Umum Status Kesehatan Siswa SDN 040494 Susuk Kecamatan Tiganderket, Kabupaten Karo. In Talenta Conference Series: Agricultural and Natural Resources (ANR) (Vol. 3, No. 2).

Lubis, N. D. A., Amelia, S., \& Balatif, R. (2020). Microbial Content Test on Sliced Papaya in Area of Universitas Sumatera Utara. Journal of Saintech Transfer, 3(2), 86-92.

LUBIS, N. D. A., NASUTION, T. A., \& PERMALU, R. K. LACK OF NUTRITION PROBLEM AMONG PRIMARY SCHOOL PUPILS IN MEDAN MUNICIPALITY.

Amelia, S., Lubis, N. D. A., \& Balatif, R. (2020). Coliform Quality Test on Tofu Samples in Three Markets in Medan City. Systematic Reviews in Pharmacy, 11(5), 619-623.

Yusraini, E., \& Lubis, N. D. A. (2020). Partial properties of young corn flour based on particle size and its effect on texture and sensory acceptability of biscuit. E\&ES, 454(1), 012117.

Amelia, S., Lubis, N. D. A., Balatif, R., Rozi, M. F., \& Sidhi, S. P. (2020, January). Antibacterial effect of Andaliman (Zanthoxylum acanthopodium) against contaminant in raw common carp (Cyprinus carpio Linnaeus). In IOP Conference Series: Earth and Environmental Science (Vol. 425, No. 1, p. 012036). IOP Publishing.

Amelia, S., Lubis, N. D. A., Rozi, M. F., \& Nababan, I. F. F. (2018, November). Safe processing method and storage time threshold for consuming of powdered-infant formula based on total plate count test. In IOP Conference Series: Earth and Environmental Science (Vol. 205, No. 1, p. 012033). IOP Publishing.

Nasution, I. K., Lubis, N. D. A., Erwin, I., \& Nusa, M. I. (2018). Cognitive Function Differences based on Hemispheric Lesions of First-Ever Ischemic Stroke Patients. Ethnicity, 31, 44-30.

Lukman, L., \& Ardian, A. (2017). PENGARUH MOTIVASI DAN DISIPLIN KERJA TERHADAP KINERJA PEGAWAI DI KANTOR KELURAHAN KADIDI KECAMATAN PANCA RIJANG KABUPATEN SIDENRENG RAPPANG. JURnal BISNIS \& KEWIRAUSAHAAN, 6(4).

Ikbal, M., \& Jabbar, A. (2019). KARAKTERISTIK BIOGRAFIS DAN KINERJA PEGAWAI DI KANTOR KECAMATAN PANCA RIJANG. Gema Kampus IISIP YAPIS Biak, 14(2), 63-70.

Erfina, L. (2018). PENGEMBANGAN MODEL PENGAMBILAN KEPUTUSAN DALAM PENGADAAN SURAT IZIN PENGGUNAAN JALAN UNTUK KEPENTINGAN PRIBADI DI KABUPATEN SIDRAP. Al Qisthi: Jurnal Sosial dan Politik.

Haeruddin, L. S. (2019). Pengaruh Prinsip Good Governance dalam Pelayanan Administrasi Surat Izin Usaha Perdagangan pada Kantor Penanaman Modal Pelayanan Terpadu Satu Pintu Kabupaten Enrekang. MUKADIMAH: Jurnal Pendidikan, Sejarah, dan IImu-ilmu Sosial, 3(2), 11-27.

Asrifan, A., \& Aeni, N. Book Review: I SPEAK FIVE LANGUAGES: FOSTERING PLURILINGUAL COMPETENCE THROUGH LANGUAGE AWARENESS By: Oliveira and Helena, Maria.

Hasriani, G., Asriati, A., Aeni, N., \& Risan, R. (2020, November). Pengajaran Passive Voice dalam Bahasa Inggris. In Seminar Nasional Pengabdian Kepada Masyarakat.

Aeni, N., Fitriani, F., \& Fitri, N. (2019). The Use of Circle Games to improve the Mastery of English Vocabulary of the Indonesian Maritime Academy Students. Journal of Educational Science and Technology (EST), 5(3), $239-244$.

Aeni, N., Jabu, B., Rahman, M. A., \& Ismail, H. (2018). Need Analysis in Developing General Maritime English (GME) Materials For Indonesian Maritime Academy AIPI Makassar. In PROCEEDINGS OF THE 65th TEFLIN INTERNATIONAL CONFERENCE (Vol. 65, No. 02).

Aeni, N., \& Panggua, S. (2017, July). A classroom action research at the second year students of indonesian maritime academy aipi makassar. In International Conference on Education, Science, Art and Technology (pp. 131-142).

Aeni, N., Jabu, B., Rahman, M. A., Ismail, H., \& Bin-Tahir, S. Z. (2018). The Students' Needs in Maritime English Class at Ami Aipi Makassar, Indonesia. Journal of Language Teaching and Research, 9(6), 1284-1292.

Aeni, N. (2021, January 4). INTRODUCTION TO THEORIES OF LEARNING. https://doi.org/10.31228/osf.io/yd2ga

M, N. A., --, M., Octaberlina, L. R., \& Lubis, N. D. A. (2021, January 22). A literature review of English Language Variation on Sociolinguistics. https://doi.org/10.31219/osf.io/ehx2q 